\title{
Peran kontrol diri dan pola asuh autoritatif terhadap prokrastinasi akademik mahasiswa Program Studi Pendidikan Dokter Fakultas Kedokteran Universitas Udayana
}

\author{
A. A Made Teguh Ananta Sukarena Putra dan I Made Rustika \\ Program Studi Sarjana Psikologi, Fakultas Kedokteran, Universitas Udayana \\ imaderustika@gmail.com
}

\begin{abstract}
Abstrak
Masalah yang dapat dialami mahasiswa terkait dengan tugas akademik adalah mahasiswa sering menunda-nunda untuk mengerjakan tugas. Perilaku menunda-nunda dalam mengerjakan sesuatu disebut dengan istilah prokrastinasi. Prokrastinasi akademik dapat dipengaruhi oleh faktor internal dan faktor eksternal. Faktor internal yang dapat memengaruhi prokrastinasi akademik adalah kemampuan individu dalam mengendalikan perilakunya agar terhindar dari tindakan yang berdampak negatif seperti prokrastinasi akademik. Kemampuan mengendalikan perilaku merupakan salah satu aspek dari kontrol diri. Faktor eksternal yang dapat memengaruhi prokrastinasi akademik adalah pengawasan yang diberikan orangtua kepada anak agar anaknya tidak melakukan perilaku negatif seperti prokrastinasi akademik. Peran orangtua dalam memberikan pengawasan kepada anak merupakan salah satu aspek dari pola asuh autoritatif. Tujuan dari penelitian ini adalah untuk mengetahui peran kontrol diri dan pola asuh autoritatif terhadap prokrastinasi akademik mahasiswa. Subjek dalam penelitian ini adalah 96 mahasiswa Program Studi Pendidikan Dokter Fakultas Kedokteran Universitas Udayana. Alat ukur yang digunakan dalam penelitian ini adalah skala kontrol diri, skala pola asuh autoritatif dan skala prokrastinasi akademik. Analisis data dilakukan teknik regresi berganda. Hasil uji regresi berganda menunjukan nilai koefisien regresi sebesar 0,760, nilai koefisien determinasi sebesar 0,577, nilai signifikansi sebesar $0,000(\mathrm{p}<0,05)$, nilai koefisien beta terstandarisasi variabel kontrol diri sebesar $-0,569$ dan nilai koefisien beta terstandarisasi variabel pola asuh autoritatif sebesar $-0,277$. Hasil tersebut menunjukan bahwa kontrol diri dan pola asuh autoritatif berperan terhadap tingkat prokrastinasi akademik mahasiswa Program Studi Pendidikan Dokter Fakultas Kedokteran Universitas Udayana. Hasil tersebut juga menunjukan bahwa kontrol diri memiliki peran lebih besar terhadap tingkat prokrastinasi akademik dibandingkan dengan pola asuh autoritatif.
\end{abstract}

Kata kunci : Kontrol diri, mahasiswa, pola asuh autoritatif, prokrastinasi akademik.

\begin{abstract}
One of the problems often experienced by students associated with academic tasks are students often procrastinate to do the task. The behavior of a person who delay doing something called procrastination. Academic procrastination can be influenced by internal factors and external factors. Internal factors that can affect academic procrastination are the individual's ability to control behavior to avoid behaviors that have negative consequences such as academic procrastination. Behavioral control is one aspect of self-control. External factors that can affect academic procrastination is the control that parents give to their children, so that their children do not perform negative behaviors such as academic procrastination. The role of parents in controlling their children is one aspect of authoritative parenting. The purpose of this research is to know the role of self-control and authoritative parenting toward academic procrastination of university student. Subjects in this study were 96-students of Medicine's Study Program Faculty of Medical Udayana University. The measuring instruments used in this study are self-control scale, authoritative parenting scale and academic procrastination scales. Data analysis was done by using multiple regression technique. The result of multiple regression test shows that the regression coefficient value is 0.760 , the determination coefficient value is 0.577 , the significance value is $0,000(p<0.05)$, the standardized beta coefficient value of self-control is -0.569 and the standardized beta coefficient value of authoritative parenting is -0.277 . The result shows that self-control and authoritative parenting play a role in the level of academic procrastination of the students Medicine's Study Program Faculty of Medical Udayana University. The results also show that self-control has a greater role in the level of academic procrastination than with authoritative parenting.
\end{abstract}

Keywords: Academic procrastination, authoritative parenting, self-control, university students. 


\section{LATAR BELAKANG}

Memasuki era modern sekarang ini, pendidikan merupakan kebutuhan yang sangat penting. Sesuai dengan isi UU No. 20 Tahun 2003 Pasal 1 Ayat (1) tentang sistem pendidikan nasional, dijelaskan bahwa pendidikan merupakan usaha yang dilakukan secara terencana dan aktif untuk mengembangkan potensi pada diri individu, sehingga dapat bermanfaat bagi diri sendiri, masyarakat, bangsa, dan negara (Departemen Pendidikan Nasional, 2003). Keberhasilan individu dalam menyelesaikan pendidikan menyebabkan individu tersebut dapat mengembangkan kemampuan dan kompetensinya yang akan bermanfaat untuk diri sendiri, masyarakat, bangsa, dan negara.

Semakin tinggi jenjang pendidikan, maka akan semakin besar tanggung jawab yang harus dilakukan. Contohnya, saat menempuh pendidikan pada jenjang perguruan tinggi mahasiswa tidak akan terlepas dari aktivitas perkuliahan serta menyelesaikan kewajiban dan tanggung jawab akademik maupun non akademik. Tugas akademik yang dimiliki mahasiswa, yaitu meliputi perkuliahan, ujian, praktikum, mengerjakan tugas, dan skripsi. Tugas yang diberikan dapat membantu mahasiswa untuk meningkatkan pemahaman terkait materi yang disampaikan. Selain untuk meningkatkan pemahaman terkait materi yang diberikan, tugas juga dapat meningkatkan rasa tanggung jawab pada mahasiswa. Hasil yang diperoleh dari tugas akademik juga akan masuk dalam bobot penilaian akademik mahasiswa tersebut.

Dalam tugas akademik akan terdapat rentang waktu yang diberikan oleh dosen untuk mengerjakan tugas dan mengumpulkan tugas tersebut. Biasanya semakin sulit tugas yang harus dikerjakan, maka akan diberikan rentang waktu yang lebih lama untuk menyelesaikannya. Dengan demikian mahasiswa harus dapat memanfaatkan waktu dengan sebaikbaiknya dalam mengerjakan tugas akademik. Salah satu masalah yang dapat dialami mahasiswa terkait dengan tugas akademik adalah mahasiswa sering kali menunda-nunda untuk mengerjakan tugas tersebut. Perilaku yang tidak dapat memanfaatkan waktu atau menunda-nunda dalam mengerjakan sesuatu disebut prokrastinasi. Sementara itu, orang yang melakukan prokrastinasi disebut dengan istilah prokrastinator (Ghufron \& Risnawita, 2012).

Masalah prokrastinasi merupakan masalah yang dapat terjadi pada sebagian besar anggota masyarakat. Prokrastinasi dapat terjadi pada hampir setiap bidang dalam kehidupan, seperti rumah tangga, keuangan, personal, sosial, pekerjaan, dan sekolah. Menurut Anom (dalam Sandra \& Djalali, 2013) semua individu dari berbagai kalangan, sedikitnya 95\% melakukan prokrastinasi dengan frekuensi kadang kala dan sekitar 15 sampai dengan $20 \%$ diantaranya telah melakukan prokrastinasi secara konsisten. Menurut Solomon dan Rothblum (dalam Ghufron \& Risnawita, 2012) prokrastinasi juga dapat terjadi dalam bidang pendidikan atau akademik.

Mahasiswa yang melakukan prokrastinasi akademik juga dapat berasal dari berbagai macam latar belakang keilmuan.
Setiap Universitas di Indonesia pastinya memiliki program studi yang menjadi favorit dibandingkan dengan program studi lainnya. Alasan suatu program studi menjadi favorit biasanya karena memiliki akreditasi yang baik atau program studi tersebut dipandang memiliki peluang yang baik dalam dunia kerja sehingga dapat memperoleh penghasilan yang tinggi. Program Studi Pendidikan Dokter Fakultas Kedokteran Universitas Udayana termasuk dalam salah satu jurusan yang paling diminati di Bali (bali.tribunnews.com, 8 Maret 2018). Mahasiswa Program Studi Pendidikan Dokter dianggap memiliki tingkat intelegensi yang tinggi serta kemampuan yang baik di bidang akademik karena telah melewati proses seleksi yang sangat ketat agar dapat masuk sebagai mahasiswa di program studi tersebut. Dengan adanya pandangan tersebut mahasiswa Program Studi Pendidikan Dokter jarang diidentikan dengan perilaku negatif di bidang akademik, seperti salah satunya adalah perilaku prokrastinasi akademik.

Dampak dari prokrastinasi akademik adalah dapat berpengaruh negatif pada prestasi mahasiswa dalam perkuliahan. Prokrastinasi merupakan perilaku yang harus dihindari di dalam bidang akademik sebab dapat menyebabkan terhambatnya kemajuan dan prestasi akademik. Mahasiswa yang melakukan prokrastinasi cenderung akan mendapatkan nilai yang tidak maksimal sehingga memengaruhi prestasi akademik mahasiswa tersebut (You, 2015). Prokrastinasi akademik juga dapat berpengaruh terhadap kualitas yang dimiliki dari sebuah institusi pendidikan. Persentase mahasiswa yang mampu lulus tepat waktu merupakan salah satu yang menentukan kualitas yang dimiliki oleh perguruan tinggi. Prokrastinasi akademik yang dilakukan mahasiswa bisa saja memengaruhi waktu untuk menyelesaikan masa studinya. Mahasiswa yang melakukan prokrastinasi akademik cenderung akan mengabiskan lebih banyak waktu untuk menyelesaikan masa studi, dibandingkan dengan mahasiswa yang tidak melakukan prokrastinasi akademik (Huda, 2015).

Ferrari (dalam Ghufron \& Risnawita, 2012) mengemukakan bahwa terdapat dua faktor yang dapat memengaruhi individu dalam melakukan prokrastinasi, yaitu faktor internal dan faktor eksternal. Faktor internal, yaitu faktor dari dalam diri individu yang menyebabkan perilaku prokrastinasi akademik. Kedua adalah karena adanya faktor eksternal, yaitu faktor yang berasal dari luar diri individu seperti adanya pengaruh dari lingkungan yang membentuk seseorang untuk melakukan prokrastinasi akademik.

Salah satu faktor internal yang dapat memengaruhi prokrastinasi akademik adalah bagaimana seseorang mampu dalam mengendalikan perilakunya untuk mencapai tujuan yang diinginkan atau menghindari diri dari konsekuensi negatif. Individu harus mampu mengendalikan perilakunya untuk segera mengerjakan tugas dan menghindari perilaku menunda-nunda agar dapat terhindar dari konsekuensi negatif akibat perilaku prokrastinasi akademik. Menurut Averill (dalam Ghufron \& Risnawita, 2012) kemampuan mengendalikan perilaku merupakan salah satu aspek dari kontrol diri. Kontrol diri menurut Goldfried dan Merbaum 
(dalam Ghufron \& Risnawita, 2012) adalah suatu kemampuan yang dimiliki indivdu untuk menyusun, membimbing, mengatur, dan mengarahkan bentuk perilaku yang dapat membawa individu tersebut ke arah konsekuensi positif. Kontrol diri dapat juga menggambarkan suatu keputusan individu melalui proses pertimbangan kognitif untuk menyatukan perilaku yang telah disusun untuk meningkatkan hasil dan tujuan yang diinginkan.

Selain faktor internal, terdapat pula faktor eksternal yang dapat memengaruhi prokrastinasi akademik. Salah satu faktor eksternal yang memengaruhi prokrastinasi akademik adalah lingkungan disekitar mahasiswa. Kondisi lingkungan yang tidak memberikan pengawasan terhadap mahasiswa akan memungkinkan mahasiswa untuk melakukan prokrastinasi akademik (Ghufron \& Risnawita, 2012). Lingkungan yang dekat dengan mahasiswa salah satunya adalah orangtua. Baumrind (dalam Santrock, 2007) menyatakan terdapat empat tipe pola asuh orangtua, yaitu otoritarian, autoritatif, permisif, dan neglectful. Keempat jenis pola asuh tersebut memiliki karakteristik yang berbedabeda yang dapat memengaruhi perkembangan anak. Pola asuh autoritatif atau disebut juga sebagai pola asuh demokratif yang merupakan pola asuh yang memberi kebebasan untuk mendorong anak menjadi mandiri namun tetap memberikan pengawasan terhadap anak. Keseimbangan antara otonomi dan kontrol atau pengawasan terhadap mahasiswa dapat berpengaruh pada saat mahasiswa mengerjakan tugas. Mahasiswa akan didorong untuk mandiri menyelesaikan tugasnya sendiri serta orangtua juga akan mengawasi dan mengontrol anaknya untuk menyelesaikan tugas tersebut. Pola asuh autoritatif juga akan membentuk perilaku mandiri pada anak untuk menyelesaikan tugas dengan tepat waktu dan memanfaatkan waktu sebaik mungkin. Menurut Papalia, Olds, dan Feldman (2011) pola asuh autoritatif dapat membantu anak terhindar dari perilakuperilaku negatif. Dengan adanya pengawasan dari orangtua, maka mahasiswa akan cenderung terhindar dari perilakuperilaku yang berdampak negatif seperti salah satunya adala perilaku prokrastinasi akademik.

Berdasarkan pemaparan tersebut terlihat bahwa terdapat peran kontrol diri dan pola asuh autoritatif terhadap prokrastinasi akademik. Untuk mengetahui apakah hal tersebut terjadi pada mahasiswa Program Studi Pendidikan Dokter Fakultas Kedokteran Universitas Udayana maka perlu adanya pembuktian lebih lanjut. Dengan demikian maka tujuan dari penelitian ini adalah untuk mengetahui apakah terdapat peran kontrol diri dan pola asuh autoritatif terhadap prokrastinasi akademik pada mahasiswa Program Studi Pendidikan Dokter Fakultas Kedokteran Universitas Udayana.

\section{METODE PENELITIAN}

\section{Variabel dan Definisi Operasional}

Variabel bebas dalam penelitian ini adalah intensitas bermain kontrol diri dan pola asuh autoritatif. Variabel tergantung yang digunakan dalam penelitian ini adalah prokrastinasi akademik. Definisi operasional dari masing-masing variabel dalam penelitian ini adalah sebagai berikut:

Prokrastinasi akademik

Prokrastinasi akademik pada penelitian ini dilihat dari perilaku mahasiswa yang menunjukkan penundaan untuk memulai dan menyelesaikan tugas, keterlambatan dalam mengerjakan tugas, kesenjangan waktu antara rencana dan kinerja aktual, dan melakukan aktivitas lain daripada mengerjakan tugas akademik. Taraf prokrastinasi akademik pada penelitian ini diukur dengan skala prokrastinasi akademik. Semakin tinggi skor total yang diperoleh, maka semakin tinggi taraf prokrastinasi akademik.

\section{Kontrol diri}

Kontrol diri dalam penelitian ini dilihat dari kemampuan mahasiswa dalam mengontrol perilaku, kognitif, dan keputusan. Taraf kontrol diri pada penelitian ini diukur dengan skala kontrol diri. Semakin tinggi skor total yang diperoleh, maka semakin tinggi taraf kontrol diri.

$\underline{\text { Pola asuh autoritatif }}$

Pola asuh autoritatif yang dimaksud dalam penelitian ini dilihat dari sikap orangtua dalam merawat, menjaga dan membimbing anaknya, yang menunjukkan keseimbangan antara pengawasan dan kebebasan kepada anak, serta orangtua yang menunjukkan sikap responsif terhadap perkembangan dan kebutuhan anaknya. Taraf pola asuh autoritatif pada penelitian ini diukur dengan skala pola asuh autoritatif. Semakin tinggi skor total yang diperoleh, maka semakin tinggi taraf pola asuh autoritatif.

\section{Subjek}

Populasi pada penelitian ini adalah Mahasiswa Program Studi Pendidikan Dokter Fakultas Kedokteran Universitas Udayana yang terdiri dari 711 mahasiswa. Subjek dalam penelitian ini memiliki karakteristik antara lain berstatus sebagai mahasiswa aktif di Program Studi Pendidikan Dokter Fakultas Kedokteran Universitas Udayana serta merupakan mahasiswa preklinik di Program Studi Pendidikan Dokter Fakultas Kedokteran Universitas Udayana.

Teknik pengambilan sampel pada penelitian ini menggunakan teknik probability sampling dengan jenis cluster sampling. Cluster Sampling (Area Sampling) atau disebut juga cluster random sampling adalah teknik yang digunakan bilamana populasi terdiri dari kelompokkelompok individu atau cluster (Sugiyono, 2011). Pada penelitian ini jumlah sampel minimum adalah sebanyak 66 orang, hal tersebut berdasarkan pada rumus yang disampaikan oleh Field (2009) yaitu $50+8$ x VB (Variabel Bebas), sehingga diperoleh jumlah sampel minimum sebanyak 66 orang.

\section{Tempat dan Waktu Penelitian}

Berdasarkan hasil pengundian, kelas yang dijadikan sampel penelitian adalah kelas Kedokteran Umum A mahasiswa Program Studi Pendidikan Dokter Universitas Udayana angkatan 2016. Pengambilan data dilakukan pada Hari Selasa, 27 Februari 2018, di ruang kuliah 3.0.1, lantai tiga, Gedung Program Studi Pendidikan Dokter Fakultas Kedokteran Universitas Udayana. Skala yang disebar oleh peneliti terdiri dari inform concern, identitas diri, petunjuk pengisian, skala kontrol diri, skala pola asuh autoritatif, dan 
skala prokrastinasi akademik. Skala yang disebarkan berjumlah 110 buah namun terdapat 14 buah skala yang tidak terisi dengan lengkap. Jadi jumlah skala yang dapat dianalisis sebanyak 96 buah.

\begin{abstract}
Alat Ukur
Terdapat tiga skala yang digunakan dalam penelitian ini yaitu skala prokrastinasi akademik, skala kontrol diri, dan pola asuh autoritatif. Ketiga skala tersebut menggunakan jenis skala Likert yang terdiri dari empat pilihan jawaban, yaitu sangat sesuai (SS), sesuai (S), tidak sesuai (TS), dan sangat tidak sesuai (STS). Skala Likert digunakan untuk mengukur sikap, pendapat, dan persepsi seseorang atau kelompok orang tentang fenomena sosial (Sugiyono, 2011). Skala kontrol diri disusun berdasarkan konsep kontrol diri yang dipelopori oleh Averill (dalam Ghufron \& Risnawita, 2012). Skala pola asuh autoritatif disusun berdasarkan pendekatan tipologi pola asuh yang dipelopori oleh Baumrind (dalam Lestari, 2016). Skala prokrastinasi akademik disusun berdasarkan teori dari Ferrari (dalam Ghufron \& Risnawita, 2012).
\end{abstract}

Menurut Azwar (2015) alat ukur yang valid dan reliabel adalah syarat untuk mampu memberikan informasi dan hasil data yang akurat. Pengukuran terhadap validitas isi dalam penelitian ini dapat dilakukan dengan teknik professional judgement. Proses pengujian validitas konstruk dilakukan dengan melakukan seleksi pada aitem-aitem skala berdasarkan korelasi aitem-total. Menurut Cronbach (dalam Azwar, 2015) koefisien korelasi aitem-total sama dengan atau lebih besar daripada 0.30 dianggap sudah memuaskan. Teknik pengukuran reliabilitas yang digunakan dalam penelitian ini adalah Cronbach Alpha. Reliabilitas skala dapat dikatakan baik apabila memiliki nilai koefisien alpha lebih besar dari 0.60 .

Hasil uji validitas skala kontrol diri memiliki koefisien korelasi aitem-total berkisar antara 0,313 sampai 0,718. Hasil uji reliabilitas skala kontrol diri dengan menggunakan teknik Cronbach Alpha menunjukkan koefisian alpha $(\alpha)$ adalah 0,916 memiliki arti bahwa skala kontrol diri mampu mencerminkan 91,6\% variasi skor murni subjek. Hasil uji validitas skala pola asuh autoritatif memiliki koefisien korelasi aitem-total berkisar antara 0,316 sampai 0,804. Hasil uji reliabilitas skala pola asuh autoritatif dengan menggunakan teknik Cronbach Alpha menunjukkan koefisian alpha $(\alpha)$ adalah 0,962 memiliki arti bahwa skala pola asuh autoritatif mampu mencerminkan 96,2\% variasi skor murni subjek. Hasil uji validitas skala prokrastinasi akademik memiliki koefisien korelasi aitem-total berkisar antara 0,307 sampai 0,702. Hasil uji reliabilitas skala prokrastinasi akademik dengan menggunakan teknik Cronbach Alpha menunjukkan koefisian alpha $(\alpha)$ adalah 0,934 memiliki arti bahwa skala prokrastinasi akademik mampu mencerminkan 93,4\% variasi skor murni subjek.

\section{Teknik Analisis Data}

Sebelum melakukan uji hipotesis data penelitian maka perlu dilakukan uji asumsi terlebih dahulu seperti uji normalitas, uji linearitas, uji multikolinearitas dan uji heteroskedastisitas. Uji normalitas data penelitian dilakukan dengan uji
Kolmogorov-Smirnov. Uji linearitas data penelitian dilakukan dengan menggunakan analisis compare mean, lalu menggunakan test of linearity. Uji multikolinearitas dilakukan dengan melihat nilai dari Variance Inflation Factor (VIF) dan nilai Tolerance. Uji heteroskedastisitas dilakukan dengan uji Glejser. Pengujian hipotesis penelitian dapat dilakukan setelah semua uji asumsi terpenuhi. Uji hipotesis pada penelitian ini menggunakan teknik uji regresi berganda. Analisis data penelitian ini dilakukan dengan bantuan perangkat lunak SPSS 20.0 release for Windows.

\section{HASIL PENELITIAN}

\section{Karakteristik Subjek}

Subjek dalam penelitian ini berjumlah 96 orang, terdiri dari 34 orang laki-laki dan 62 orang perempuan. Rentang usia subjek dalam penelitian ini adalah 17-21 tahun dengan mayoritas subjek berusia 19 tahun dengan persentase 59,4\%. Mayoritas pendidikan ayah subjek pada penelitian ini adalah S1 dengan presentase sebesar $47,9 \%$. Mayoritas ibu subjek memiliki pendidikan terakhir S1 dengan persentase sebesar $39,6 \%$. Mayoritas ayah subjek memiliki pekerjaan sebagai wiraswasta dengan persentase sebesar 33,3\%. Mayoritas ibu subjek bekerja sebagai ibu rumah tangga dengan persentase sebesar $40,6 \%$.

\section{Deskripsi Data Penelitian}

Hasil deskripsi data penelitian yaitu kontrol diri, pola asuh autoritatif, dan prokrastinasi akademik dapat dilihat pada tabel 1 (terlampir).

Hasil deskripsi pada tabel 1 menunjukkan bahwa variabel kontrol diri memiliki nilai mean empiris yang berbeda secara signifikan terhadap mean teoretisnya. Hal ini dapat dilihat dari nilai probabilitas uji one-sample $t$ test sebesar 0,000 $(\mathrm{p}<\alpha)$. Nilai mean empiris yang lebih besar dari mean teoretis mengindikasikan bahwa subjek memiliki tingkat kontrol diri yang cenderung tinggi. Tabel 1 juga menunjukkan bahwa variabel pola asuh autoritatif memiliki nilai mean empiris yang berbeda secara signifikan terhadap mean teoretisnya. Hal ini dapat dilihat dari nilai probabilitas uji one-sample t test sebesar $0,000(\mathrm{p}<\alpha)$. Nilai mean empiris yang lebih besar dari mean teoretis mengindikasikan bahwa subjek memiliki tingkat pola asuh autoritatif yang cenderung tinggi. Selanjutnya, pada tabel 1 juga menunjukan bahwa variabel prokrastinasi akademik memiliki nilai mean empiris yang berbeda secara signifikan terhadap mean teoretisnya. Hal ini dapat dilihat dari nilai probabilitas uji one-sample $t$ test sebesar $0,000(\mathrm{p}<\alpha)$. Nilai mean empiris yang lebih kecil dari mean teoretis mengindikasikan bahwa subjek memiliki tingkat prokrastinasi akademik yang cenderung rendah.

\section{Uji Asumsi}

Uji normalitas dilakukan guna mengetahui sebaran skor variabel penelitian memiliki ditribusi yang normal atau tidak. Uji normalitas dilakukan dengan menggunakan KolmogorovSmirnov. Apabila uji Kolmogorov-Smirnov menunjukkan probabilitas lebih besar daripada 0.05, maka data dikatakan berdistribusi secara normal. Sedangkan jika probabilitas data lebih kecil dari 0.05 , berarti data tidak berdistribusi normal 
(Hamdi \& Bahruddin, 2014).

Berdasarkan hasil uji normalitas pada tabel 2 (terlampir) menunjukkan bahwa sebaran data pada variabel kontrol diri berdistribusi normal dengan nilai Kolmogorov-Smirnov 0,934 dan signifikansi 0,347 ( $>0,05)$. Tabel 2 juga menunjukan bahwa sebaran data pada variabel pola asuh autoritatif berdistribusi normal dengan nilai Kolmogorov-Smirnov 1,056 dan signifikansi 0,215 ( $\mathrm{p}>0,05)$. Tabel 2 juga menunjukkan bahwa sebaran data pada variabel prokrastinasi akademik berdistribusi normal dengan nilai Kolmogorov- Smirnov 0,613 dan signifikansi $0,846(\mathrm{p}>0,05)$.

Uji linearitas dilakukan untuk mengetahui apakah terdapat hubungan yang linear antara variabel bebas dengan variabel terikat. Uji linearitas data dilakukan dengan menggunakan analisis compare mean, lalu menggunakan test of linearity. Hubungan kedua variabel dikatakan linear apabila memiliki nilai signifikansi deviation from linearity bernilai lebih besar dari 0,05 ( $p>0,05)$ (Pramesti, 2016). Menurut Gani dan Amalia (2015) uji linearitas juga dapat dilihat dari nilai signifikansi linearity, apabila nilai signifikansi linearity lebih kecil dari $0,05(\mathrm{p}<0,05)$, maka terdapat hubungan yang linear antar variabel.

Berdasarkan hasil uji linearitas pada tabel 3 (terlampir) menunjukkan bahwa terdapat hubungan yang linear antara variabel dukungan kontrol diri dengan prokrastinasi akademik, serta antara variabel pola asuh autoritatif dengan prokrastinasi akademik. Hal ini ditunjukkan melalui nilai taraf signifikansi linearity antara variabel kontrol diri dan prokrastinasi akademik yaitu sebesar $0,000(\mathrm{p}<0,05)$ dan memiliki nilai taraf signifikansi deviation from linearity sebesar $0,710(\mathrm{p}>0,05)$, serta nilai taraf signifikansi linearity antara variabel pola asuh autoritatif dan prokrastinasi akademik yaitu sebesar 0,000 $(\mathrm{p}<0,05)$ dan memiliki nilai taraf signifikansi Deviation from Linearity sebesar 0,564 ( $>>0,05)$.

Uji multikolonearitas bertujuan untuk menguji apakah model regresi ditemukan adanya korelasi antar variabel bebas. Model regresi yang baik seharusnya tidak terjadi korelasi di antara variabel bebas atau tidak terjadi multikolinearitas. Pengujian ini dilakukan dengan mengukur besar korelasi antar variabel bebas. Apabila dua variabel bebas terbukti berkorelasi secara kuat, maka secara logika persamaan regresinya cukup diwakili oleh salah satu variabel. Adanya multikolinearitas dapat dilihat dari tolerance value dan nilai variance inflation factor (VIF). Jika nilai VIF $\leq 10$ dan nilai Tolerance $\geq 0,1$, maka dinyatakan tidak terjadi multikolinearitas (Yudiaatmaja, 2013).

Berdasarkan hasil uji multikolinearitas pada tabel 4 (terlampir) menunjukkan bahwa kedua variabel penelitian yaitu kontrol diri dan pola asuh autoritatif tidak terjadi multikolinearitas atau tidak terjadi korelasi. Hal ini ditunjukkan berdasarkan pada variabel kontrol diri dan pola asuh autoritatif yang sama-sama menunjukkan nilai Tolerance sebesar 0,688 (Tolerance $>0,1$ ) dan nilai Variance Inflation Factor (VIF) sebesar 1,454 $(\mathrm{VIF}<10)$.

Uji heteroskedastisitas berfungsi untuk menguji model regresi yang dilakukan, apakah terjadi varian yang berbeda dari residual pada satu pengamatan dengan pengamatan yang lain. Model regresi dapat dikatakan heteroskedastisitas apabila varian dari residual pada satu pengamatan dengan pengamatan lain berbeda, sedangkan apabila varian dari residual pada satu pengamatan dengan pengamatan lain sama maka model regresi disebut homoskedastisitas. Teknik uji regresi dikatakan baik apabila tidak terjadi heteroskedastisitas di dalamnya. Uji heteroskedastisitas dalam penelitian ini menggunakan uji Glejser. Adanya heterokedastisitas dapat dilihat dari hasil uji Glejser, apabila nilai signifikansi lebih kecil $0.05(\mathrm{p}<0.05)$, maka dikatakan terdapat heterokedastisitas, sedangkan jika nilai signifikansi lebih besar dari 0.05 ( $\mathrm{p}>0.05)$, maka dikatakan tidak terdapat heterokedastisitas (Sutopo \& Slamet, 2017).

Berdasarkan hasil uji heteroskedastisitas pada tabel 5 (terlampir) menunjukkan bahwa kedua variabel penelitian yaitu kontrol diri dan pola asuh autoritatif tidak terjadi heterokedastisitas. Hal ini ditunjukkan berdasarkan pada variabel kontrol diri memiliki nilai signifikansi 0,412 ( $p>0,05)$, serta pada variabel pola asuh autoritatif juga menunjukkan nilai signifikansi lebih besar dari $0,05(\mathrm{p}>0,05)$, yaitu sebesar 0,143 .

\section{Uji Hipotesis}

Uji hipotesis statistik yang digunakan dalam penelitian ini adalah uji regresi berganda (Multiple Regression). Menurut Yudiaatmaja (2013) regresi berganda digunakan untuk meprediksi hubungan antara dua variabel bebas atau lebih dengan satu variabel terikat. Selain mengukur kekuatan hubungan antara dua variabel atau lebih, teknik regresi berganda juga menunjukkan arah hubungan antara variabel terikat dan variabel bebas. Menurut Santoso (2014) pengambilan keputusan terkait hipotesis mana yang akan diterima ditentukan berdasarkan nilai signifikansi apabila nilai signifikansi lebih kecil dari $0.05($ sig<0.05) maka, Ha diterima dan H0 ditolak. Yang berarti variabel bebas berpengaruh secara signifikan terhadap variabel terikat. Jika nilai signifikansi lebih besar dari $0.05(\mathrm{p}>0.05)$, maka Ha ditolak dan H0 diterima yang berarti variabel bebas tidak berpengaruh secara signifikan terhadap variabel terikat.

Berdasarkan hasil pada tabel 6 (terlampir) menunjukkan nilai $\mathrm{R}$ sebesar 0,760 , hal ini menunjukkan bahwa terdapat peran yang kuat antara variabel bebas yaitu kontrol diri dan pola asuh autoritatif terhadap variabel terikat yaitu prokrastinasi akademik. Nilai koefisien determinasi (R Square) sebesar 0,577 menunjukkan variabel bebas memiliki peran sebesar $57,7 \%$ terhadap variabel terikat, sedangkan variabel yang tidak diteliti memiliki peran sebesar $42,3 \%$ terhadap variabel terikat.

Berdasarkan hasil uji regresi berganda pada tabel 7 (terlampir) menunjukkan bahwa nilai $\mathrm{F}$ hitung yang bernilai 63,392 lebih besar dari nilai $\mathrm{F}$ tabel yang bernilai 3,09 dengan taraf signifikansi sebesar 5\%, sampel sebanyak 96 dan derajat kebebasan sebesar 2. Tabel 7 juga menunjukkan nilai signifikansi sebesar $0,000 \quad(p<0,05), \quad$ sehingga dapat disimpulkan bahwa $\mathrm{H} 0$ ditolak dan Ha pada hipotesis mayor dalam penelitian ini diterima. Jadi, terdapat peran kontrol diri 
dan pola asuh autoritatif terhadap prokrastinasi akademik pada mahasiswa Program Studi Pendidikan Dokter Fakultas Kedokteran Universitas Udayana.

Berdasarkan hasil pada tabel 8 (terlampir) menunjukkan variabel kontrol diri memiliki koefisien beta terstandarisasi sebesar -0,569, nilai t sebesar -7,001 dan taraf signifikansi sebesar $0,000(p<0,05)$, sehingga dapat dikatakan bahwa kontrol diri berperan secara signifikan terhadap prokrastinasi akademik. Variabel pola asuh autoritatif memiliki koefisien beta terstandarisasi sebesar $-0,277$, nilai t sebesar $-3,404$ dan taraf signifikansi sebesar $0,001 \quad(\mathrm{p}<0,05)$, sehingga dapat dikatakan bahwa pola asuh autoritatif berperan secara signifikan terhadap prokrastinasi akademik.

Variabel kontrol diri memiliki nilai koefesien beta terstandarisasi yang bernilai $-0,569$, sedangkan pada variabel pola asuh autoritatif memiliki nilai koefesien beta terstandarisasi yang bernilai -0,277. Koefesien beta terstandarisasi digunakan untuk membandingkan variabel bebas, sehingga dapat menemukan variabel bebas manakah yang memiliki pengaruh yang lebih dominan terhadap variabel terikat. Nilai negatif yang ditunjukkan memiliki arti bahwa variabel bebas berperan dalam menurunkan tingkat variabel terikat. Variabel kontrol diri memiliki nilai koefesien beta terstandarisasi yang lebih besar dari variabel pola asuh autoritatif. Jadi, variabel kontrol diri memiliki peran lebih besar dalam menurunkan tingkat prokrastinasi akademik dibandingkan dengan pola asuh autoritatif.

Rumus garis regresi berganda yang digunakan dalam penelitian ini adalah :

$$
\begin{aligned}
& \mathrm{Y}=294,219-1,229 \mathrm{X} 1-0,609 \mathrm{X} 2 \\
& \text { Keterangan : } \\
& \mathrm{Y}=\text { Prokrastinasi akademik } \\
& \mathrm{X} 1=\text { Kontrol diri } \\
& \mathrm{X} 2=\text { Pola asuh autoritatif }
\end{aligned}
$$

a. Konstata sebesar 294,219 menunjukkan bahwa jika variabel kontrol diri dan pola asuh autoritatif memliki nilai 0 , maka nilai prokrastinasi akademik yang dimiliki akan sebesar 294,219.

b. Koefesien regresi X1 sebesar -1,229. Nilai negatif yang ditunjukkan memiliki arti bahwa variabel bebas berperan dalam menurunkan tingkat variabel terikat. Jadi, setiap terjadi peningkatan satuan nilai dari variabel kontrol diri, maka nilai variabel prokrastinasi akademik akan mengalami penurunan sebesar 1,229.

c. Koefesien regresi X2 sebesar -0,609. Nilai negatif yang ditunjukkan memiliki arti bahwa variabel bebas berperan dalam menurunkan tingkat variabel terikat. Jadi, setiap terjadi peningkatan satuan nilai dari variabel pola asuh autoritatif, maka nilai variabel prokrastinasi akademik akan mengalami penurunan sebesar 0,609.
Rangkuman hasil uji hipotesis mayor dan hipotesis minor pada penelitian ini dapat dilihat pada tabel 9 (terlampir).

\section{PEMBAHASAN DAN KESIMPULAN}

Berdasarkan hasil uji hipotesis dengan teknik analisis regresi berganda, menunjukkan bahwa hipotesis mayor pada penelitian ini diterima yaitu, terdapat peran kontrol diri dan pola asuh autoritatif terhadap prokrastinasi akademik pada mahasiswa Program Studi Pendidikan Dokter Fakultas Kedokteran Universitas Udayana. Hipotesis mayor dikatakan diterima berdasarkan pada hasil analisis yang menunjukkan nilai signifikansi sebesar 0,000 yang bernilai lebih kecil dari $0,05(\mathrm{p}<0,05)$. Tingkat prokrastinasi akademik pada subjek dipengaruhi oleh variabel kontrol diri dan pola asuh autoritatif. Hasil analisis menunjukkan nilai $\mathrm{R}$ sebesar 0,760 yang menunjukkan bahwa terdapat peran yang kuat antara variabel bebas yaitu kontrol diri dan pola asuh autoritatif terhadap variabel terikat yaitu prokrastinasi akademik. Hal tersebut sesuai dengan pendapat dari Ghufron dan Risnawita (2012), bahwa prokrastinasi akademik dapat dipengaruhi oleh faktor yang berasal dari dalam individu (internal) yaitu kontrol diri dan faktor yang berasal dari luar (eksternal) yaitu pola asuh autoritatif. Dalam penelitian ini juga menunjukkan koefisien determinasi ( $\mathrm{R}$ Square) yang bernilai sebesar 0,577 yang berarti bahwa variabel bebas dalam penelitian ini yaitu kontrol diri dan pola asuh autoritatif memiliki peran sebesar $57,7 \%$ terhadap variabel terikat yaitu prokrastinasi akademik, sedangkan sisanya 42,3\% dipengaruhi oleh variabel lain yang tidak diteliti dalam penelitian ini.

Berdasarkan hasil analisis penelitian menunjukkan variabel kontrol diri memiliki koefisien beta terstandarisasi sebesar 0,569, dengan nilai $\mathrm{t}$ sebesar -7,001 dan taraf signifikansi sebesar 0,000 $(\mathrm{p}<0,05)$, sehingga dapat dikatakan bahwa kontrol diri berperan secara signifikan dalam menurunkan tingkat prokrastinasi akademik. Hasil penelitian ini sesuai dengan hasil penelitian yang dilakukan oleh Muhid (2009), yang menyatakan bahwa kontrol diri memengaruhi kecenderungan perilaku prokrastinasi akademik mahasiswa. Hal serupa juga disampaikan oleh Ghufron dan Risnawita (2012) yang mengatakan faktor internal yang dapat brepengaruh terhadap prokrastinasi akademik dapat berupa kondisi psikologis yang merupakan aspek-aspek psikologis yang ada dalam individu yang dapat memengaruhi perilaku prokrastinasi akademik, salah satu aspek psikologis yang dimiliki individu yang dapat berperan dalam perilaku prokrastinasi akademik adalah kontrol diri.

Menurut hasil penelitian dari Aziz dan Rhardjo (2013) salah satu faktor penyebab terjadinya prokrastinasi adalah pleasureseeking atau pencari kesenangan. Seseorang yang mencari kenyamanan cenderung tidak ingin terlepas dari situasi yang membuat nyaman tersebut dan memiliki kontrol impuls atau stimulus yang rendah. Jika mahasiswa memiliki kecenderungan tinggi dalam mencari situasi yang nyaman, maka mahasiswa tersebut akan memiliki hasrat yang kuat untuk bersenang-senang dan menghindar dari tanggung jawab dalam mengerjakan tugas akademik. Menurut Berndt (dalam 
Ghufron \& Risnawita, 2012) ketika individu dengan kontrol diri yang tinggi dihadapkan pada dua perilaku yeng sama-sama menghasilkan akibat tertentu, individu tersebut mampu untuk menunda kepuasan yang lebih kecil dan memutuskan untuk menunggu hingga memperoleh hasil yang lebih memuaskan. Apabila mahasiswa yang memiliki kontrol diri tinggi dihadapkan pada suatu pilihan antara mengerjakan tugas atau melakukan kegiatan lain yang lebih menyenangkan, maka mahasiswa tersebut akan cenderung menyelesaikan tugasnya terlebih dahulu agar mendapatkan hasil yang lebih memuaskan, daripada memilih melakukan kegiatan lain yang lebih menyenangkan yang hanya menghasilkan kepuasan sementara.

Hasil analisis data pada penelitian ini menunjukkan variabel pola asuh autoritatif memiliki koefisien beta terstandarisasi sebesar -0,277, dengan nilai $t$ sebesar -3,404 dan taraf signifikansi sebesar 0,001 yang bernilai lebih kecil dari 0,05 $(\mathrm{p}<0,05)$, sehingga dapat dikatakan bahwa pola asuh autoritatif berperan secara signifikan dalam menurunkan tingkat prokrastinasi akademik. Hal tersebut sesuai dengan pendapat Ghufron dan Risnawita (2012) bahwa faktor eksternal yang memengaruhi munculnya prokrastinasi yaitu peran pola asuh yang diterapkan orangtua memiliki pengaruh bagi kecenderungan seseorang melakukan prokrastinasi. Hasil penelitian Ferrari dan Ollivete (dalam Ghufron \& Risnawita, 2012) menemukan bahwa tingkat pengasuhan otoriter ayah dapat menyebabkan kencenderungan seseorang untuk melakukan prokrastinasi dan tingkat pengasuhan autoritatif ayah tidak menunjukkan kecendrungan prokrastinasi pada anaknya. Kondisi lingkungan dengan pengawasan yang rendah juga merupakan lingkungan yang menyebabkan seseorang cenderung melakukan prokrastinasi. Pengawasan yang rendah berarti lingkungan tidak mengontrol individu dalam melakukan tugasnya dan tidak memberikan respon jika individu tersebut tidak mengerjakan dan menyelesaikan tugas.

Pada mahasiswa yang memiliki tingkat pola asuh autoritatif yang tinggi maka akan dituntut dan dikontrol untuk menyelesaikan tugasnya secara mandiri. Orangtua akan memberikan pengawasan dan kebebasan kepada anaknya untuk menggunakan strategi dan caranya sendiri dalam mengerjakan tugas. Dengan adanya kebebasan atau otonomi yang diberikan oleh orangtua, maka mahasiswa akan dapat mengeksplorasi kemampuannya sendiri dan memunculkan keinginan untuk mengerjakan tugas secara mandiri. Hal tersebut dapat terjadi karena dalam pola asuh autoritatif terdapat aspek demandingness. Menurut Baumrind (dalam Lestari, 2016) aspek demandingness pada orangtua autoritatif akan menunjukkan keseimbangan antara tuntutan dan kebebasan yang diberikan kepada anaknya. Menurut Steinberg (dalam Lestari, 2016) dengan pola asuh autoritatif dapat mendorong anak untuk berprestasi secara akademis, yang mengindikasikan bahwa anak tidak menunjukkan perilaku negatif seperti prokrastinasi akademik. Adanya aspek responsiveness dalam pola asuh autoritatif dimana menunjukkan sikap responsif orangtua terhadap kebutuhan anaknya, baik kebutuhan psikologis maupun kebutuhan material juga dapat membantu anak dalam membantu anak dalam mengerjakan tugas.
Pada penelitian ini variabel kontrol diri memiliki nilai koefesien beta terstandarisasi yang bernilai $-0,569$ sedangkan pada variabel pola asuh autoritatif memiliki nilai koefesien beta terstandarisasi bernilai sebesar $-0,277$. Nilai negatif yang ditunjukkan memiliki arti bahwa variabel bebas berperan dalam menurunkan tingkat variabel terikat. Variabel kontrol diri memiliki nilai koefesien beta terstandarisasi yang lebih besar dari variabel pola asuh autoritatif. Jadi, variabel kontrol diri memiliki peran lebih besar dalam menurunkan tingkat prokrastinasi akademik dibandingkan dengan pola asuh autoritatif. Menurut Averill (dalam Ghufron \& Risnawita, 2012) individu yang memiliki kemampuan kontrol diri yang baik akan mampu mengontrol perilakunya sendiri dan apabila tidak mampu mengontrol dirinya dengan baik maka individu akan menggunakan sumber eksternal atau berasal dari luar dirinya. Dengan demikian menunjukkan bahwa mahasiswa Program Studi Pendidikan Dokter Fakultas Kedokteran Universitas Udayana memilki tingkat kontrol diri yang tinggi sehingga mampu mengontrol dirinya sendiri untuk tidak melakukan prokrastinasi akademik. Dengan adanya kemampuan kontrol diri yang tinggi tersebut maka tidak perlu adanya peran kontrol atau pengawasan yang lebih tinggi dari luar diri seperti pengawasan atau kontrol dari orangtua agar mahasiswa tidak melakukan prokrastinasi akdemik. Selain itu, menurut Santrock (2007) pengawasan atau kontrol yang diberikan oleh orangtua saat anak menginjak masa remaja akan cenderung berkurang. Hal tersebut dikarenakan pada saat remaja anak telah memiliki pemikirannya sendiri sehingga dapat mengatur dan menentukan apa yang baik dan buruk untuk dirinya. Penjelasan tersebut mempertegas bahwa pada mahasiswa kontrol diri memiliki peran yang lebih besar dibandingkan dengan pola asuh autoritatif terhadap perilaku prokrastinasi akademik.

Pada penelitian ini juga ditemukan bahwa mayoritas subjek memiliki tingkat kontrol diri yang tinggi. Hal tersebut menunjukkan mayoritas mahasiswa memiliki kemampuan yang tinggi dalam mengontrol perilaku, kognitif, dan keputusan, sehingga mampu mengendalikan tingkah laku dalam berbagai situasi secara mandiri agar sesuai dengan lingkungan sehingga memperoleh konsekuensi positif atau terhindar dari konsekuensi negatif, serta melakukan pertimbangan-pertimbangan terlebih dahulu sebelum memutuskan sesuatu. Menurut Ghufron dan Risnawita (2012) faktor yang dapat memengaruhi kontrol diri seseorang adalah faktor usia dan kematangan. Semakin bertambahnya usia seseorang akan semakin baik kontrol dirinya, individu yang matang secara psikologis akan mampu mengontrol perilakunya dengan lebih baik karena telah mampu mempertimbangkan hal-hal yang baik dan buruk bagi dirinya. Menurut Monks et al. (2009) rentang usia mahasiswa berusia 18-21 tahun, termasuk dalam tahap perkembanagan remaja akhir. Menurut teori dari Piaget (dalam Santrock, 2007), kemampuan kognitif pada usia remaja telah mencapai tahap operasional formal. Remaja telah lebih mampu mempertimbangkan suatu kemungkinan untuk menyelesaikan suatu masalah dengan mempertimbangkan berbagai kemungkinan. Pada saat remaja kemampuan mengontrol diri berkembang seiring dengan kematangan emosi. 
Hasil kategorisasi pola asuh autoritatif subjek, menunjukkan bahwa mayoritas subjek memiliki tingkat pola asuh autoritatif yang tinggi. Berarti, orangtua mahasiswa menunjukkan sikap yang seimbangan antara pengawasan dan kebebasan dalam merawat, menjaga dan membimbing anaknya, serta menunjukkan sikap responsif terhadap perkembangan dan kebutuhan anak. Menurut Edward (2006) pola asuh dapat dipengaruhi oleh tingkat pendidikan orangtua. Pendidikan dan pengalaman orangtua dalam perawatan anak akan memengaruhi persiapan mereka menjalankan pengasuhan. Hal yang sama juga disampaikan oleh Maccoby dan Mcloby (dalam Madyawati, 2016) bahwa pendidikan orangtua dapat memengaruhi pola asuh yang diterapkan. Latar belakang pendidikan orangtua dapat memengaruhi pola pikir orangtua sehingga akan berpengaruh terhadap aspirasi atau harapan orangtua terhadap anak. Semakin tinggi tingkat pendidikan orangtua akan memengaruhi informasi yang dimiliki oleh orangtua dalam menjalankan pola asuh yang tepat untuk anaknya. Selain itu faktor kondisi sosial ekonomi juga dapat memengaruhi pola asuh orangtua.

Berdasarkan hasil uji one-sample t test juga menunjukan hasil bahwa terdapat perbedaan yang signifikan antara mean empiris dan mean teoretis dari skala prokrastinasi akademik, dimana mean empiris dari skala prokrastinasi akademik lebih kecil dari mean teoretisnya. Hal tersebut mengindikasikan bahwa subjek memiliki tingkat prokrastinasi akademik yang cenderung rendah. Tingkat prokrastinasi tersebut dapat terjadi karena subjek memiliki tingkat kontrol diri dan pola asuh autoritatif yang tinggi, dimana pada penelitian ini juga telah menunjukkan hasil bahwa kontrol diri dan pola asuh autoritatif berperan secara signifikan dalam menurunkan tingkat prokrastinasi akademik. Sesuai dengan pendapat Ghufron dan Risnawita (2012) bahwa prokrastinasi akademik dapat dipengaruhi oleh kontrol diri dan pola asuh yang diterapkan orangtua.

Pada penelitian ini masih memiliki beberapa keterbatasan yaitu, pada pengambilan data penelitian masih terdapat beberapa skala hasil pengambilan data yang tidak terisi dengan lengkap sehingga tidak layak untuk dianalisis, hal tersebut dikarenakan subjek yang cenderung kurang serius dalam menjawab skala penelitian. Kurang seriusnya subjek dalam mengisi skala dapat terjadi karena subjek ingin cepat-cepat menyelesaikan proses pengambilan data, namun harus mengisi skala dengan jumlah aitem yang cukup banyak dari tiga jenis skala yang diberikan secara bersamaan.

Berdasarkan hasil analisis penelitian dalam bab sebelumnya, maka kesimpulan dari penelitian ini adalah sebagai berikut :

1. Kontrol diri dan pola asuh autoritatif berperan dalam menurunkan tingkat prokrastinasi akademik mahasiswa Program Studi Pendidikan Dokter Fakultas Kedokteran Universitas Udayana.

2. Kontrol diri berperan dalam menurunkan tingkat prokrastinasi akademik mahasiswa Program Studi Pendidikan Dokter Fakultas Kedokteran Universitas Udayana.
3. Pola asuh autoritatif berperan dalam menurunkan tingkat prokrastinasi akademik mahasiswa Program Studi Pendidikan Dokter Fakultas Kedokteran Universitas Udayana.

4. Mayoritas mahasiswa Program Studi Pendidikan Dokter Fakultas Kedokteran Universitas Udayana memiliki taraf kontrol diri yang tinggi.

5. Mayoritas mahasiswa Program Studi Pendidikan Dokter Fakultas Kedokteran Universitas Udayana memiliki taraf pola asuh autoritatif yang tinggi.

6. Mayoritas mahasiswa Program Studi Pendidikan Dokter Fakultas Kedokteran Universitas Udayana memiliki tingkat prokrastinasi akademik yang cenderung rendah.

Berdasarkan kesimpulan diatas, maka saran yang dapat diberikan kepada pihak mahasiswa yaitu hasil penelitian menunjukkan bahwa mahasiswa Program Studi Pendidikan Dokter Fakultas Kedokteran Universitas Udayana memiliki tingkat prokrastinasi akademik yang cenderung rendah. Adanya informasi tersebut diharapkan agar mahasiswa dapat memunculkan kesadaran untuk berusaha menghindari perilaku prokrastiasi akademik. Agar dapat terhindar dari perilaku prokrastinasi akademik, mahasiswa harus meningkatkan kemampuan kontrol perilaku dan menanamkan pemikiran yang memandang tugas akademik sebagai suatu hal yang positif dan penting, serta meningkatkan kemampuan dalam mengontrol keputusan agar dapat mengambil keputusan yang tepat sehingga dapat terhindar dari prokrastinasi akademik yang memiliki konsekuensi negatif seperti tugas yang tidak terselesaikan dengan maksimal dan dapat menghambat prestasi akademik.

Saran bagi orangtua diharapkan menerapkan pola asuh yang tepat dan sesuai dengan usia dan kondisi yang sedang dialami anaknya sebagai seorang mahasiswa. Orangtua diharapkan menunjukkan keseimbangan antara kontrol dan pemenuhan kebutuhan anak. Sikap yang tepat bagi orangtua adalah memberikan pola asuh autoritatif, dimana dapat memberikan otonomi bagi mahasiswa agar dapat mengeksplorasi kemampuannya sendiri, serta orangtua tetap memberikan pengawasan dan kontrol agar anaknya tidak melakukan perilaku negatif seperti salah satunya adalah prokrastinasi akademik.

Saan bagi institusi pendidikan diharapkan mampu menerapkan gaya pengajaran yang demokratis layaknya pola asuh autoritatif. Hal tersebut dapat dilakukan dengan melakukan workshop untuk mendiskusikan sistem pengajaran yang tepat layaknya pola asuh autoritatif, sehingga dapat memebantu mahasiswa terhindar dari perilaku prokrastinasi akademik. Institusi pendidikan juga dapat menyelenggarakan program-program tertentu dalam upaya peningkatan kemampuan kontrol diri dan memberikan informasi kepada mahasiswa terkait perilaku prokrastinasi akademik yang berdampak negatif bagi mahasiswa, dengan harapan dapat menurunkan tingkat prokrastinasi akademik. Bentuk program tersebut bisa berupa memberikan bimbingan di awal perkuliahan saat masa orientasi mahasiswa, bimbingan khusus bagi mahasiswa yang mengalami 
kesulitan akademik, seminar dan pelatihan- pelatihan yang meningkatkan kemampuan kontrol diri.

Saran bagi penelitian selanjutnya dapat menggunakan variabel bebas lain selain variabel yang telah digunakan dalam penelitian ini. Hal tersebut dilakukan untuk mengetahui variabel-variabel lain yang berhubungan terhadap prokrastinasi akademik, dikarenakan masih terdapat variabel-variabel lain yang dapat berperan terhadap prokrastinasi akademik. Penelitian selanjutnya juga dapat melakukan penelitian pada populasi yang lebih luas untuk memperluas generalisasi penelitian terkait prokrastinasi akademik. Bagi penelitian selanjutnya apabila pengambilan data menggunakan lebih dari satu jenis skala, disarankan agar memberikan masing-masing jenis skala pada waktu yang berbeda-beda.

\section{DAFTAR PUSTAKA}

Aziz, A, \& Rhardjo. P. (2013). Faktor-faktor prokrastinasi akademik pada mahasiswa tingkat akhir yang menyusun skripsi di Universitas Muhamadiyah Purwekerto tahun akademik 2011/2012. PSYCHO IDEA 11(1), 61-68. Diakses dari http://jurnalnasional.ump.ac.id/index.php/PSYCHOIDE A/article/view/257/253. Diakses pada tanggal 26 Juni 2018.

Azwar, S. (2015). Reliabilitas dan validitas edisi 4. Yogyakarta: Pustaka Belajar.

Azwar, S. (2015). Penyusunan skala psikologi edisi 2. Yogyakarta: Pustaka Belajar.

Bali.tribunnews.com, 08 Maret (2018). SNMPTN di Universitas Udayana resmi ditutup, ini jurusan yang paling diminati. Diambil dari http://bali.tribunnews.com/2018/03/08/snmptn-diuniversitas-udayana-resmi-ditutup-ini-jurusan-yangpaling-diminati. Diakses pada tanggal 26 Juni 2018.

Departemen Pendidikan Nasional, (2003). Undang-Undang nomor 20 tahun 2003, Tentang Sistem Pendidikan Nasional, Jakarta: Depdiknas. Diakses dari https://www.komisiinformasi.go.id/regulasi/download/i d/10. Diakses pada tanggal 7 Maret 2017.

Edward, Drew, C. (2006). Ketika anak sulit diatur: Panduan orangtua untuk mengubah masalah perilaku anak Bandung: PT. Mizan Utama.

Gani, Irwan \& Amalia, Siti. (2015). Alat analisis data; Aplikasi statistik untuk penelitian bidang ekonomi dan sosial. Yogyakarta: ANDI.

Ghufron, N.M. \& Risnawita, R. (2012). Teori-Teori psikologi. Yogyakarta: Ar- Ruz Media.

Hamdi, A.S \& Bahruddin, A. (2014). Metode penelitian kuantitatif aplikasi dalam pendidikan. Yogyakarta: Deepublish.

Huda, M. J. N. (2015). Perbandingan prokrastinasi akademik menurut pilihan jenis kelamin di UIN Sunan Kalijaga Yogyakarta. Palastren, 8(2), 424-438. Diakses dari http://download.portalgaruda.org/article.php?article $=40$ $1100 \& v a l=6786 \&$ title $=$ PERBANDINGAN\%20PROKR ASTINASI\%20AKADEMIK\%20MENURUT\%20PIL AHAN\%20JENIS\%20KELAMIN\%20DI\%20UIN\%20 SUNAN\%20KALIJAGA\%20YOGYAKARTA. Diakses pada tanggal 26 Juni 2018.

Lestari, Sri. (2016). Psikologi keluarga: Penanaman nilai dan penanganan konflik dalam keluarga. Jakarta: Kharisma Putra Utama.

Madyawati, L. (2016). Strategi pengembangan bahasa pada anak.
Jakarta: Prenada Media Group.

Monks F.J., Knoers A.M.P \& Haditono. S.R. (2009). Psikolog perkembangan: Pengantar dalam berbagai bagiannya. Yogjakarta: Gajahmada University Press.

Muhid, A. (2009). Hubungan antara self -control dan self - efficacy dengan kecenderungan perilaku prokrastinasi akademik mahasiswa Fakultas Dakwah IAIN Sunan Ampel Surabaya. Jurnal Ilmu Dakwah, 18(1), 578. Diakses dari http://www.librarygunadarma.com. Diakses pada tanggal 8 Maret 2017.

Papalia, D.E, Olds, S.W, \& Feldman, R.D. (2011). Human development: Psikologi perkembangan edisi kesembilan bagian V s/d IX. Jakarta: Kencana Prenada Media Grup.

Pramesti, Getut. (2016). Statistika lengkap secara teori dan aplikasi dengan SPSS 23. Jakarta: PT. Elex Media Komputindo.

Sandra, K.I \& Djalali, M.A (2013). Manajemen waktu, efikasi-diri dan prokrastinasi. Jurnal Psikologi Indonesia, 2(3) 217 222. Diakses dari http://jurnal.untagsby.ac.id/index.php/persona/article/download/140/5. Diakses pada tanggal 7 Maret 2017.

Santoso, S. (2014). Panduan lengkap SPSS versi 20. Jakarta: Elex Media Komputindo.

Santrock, J.W. (2007). Adolescence: Perkembangan remaja. Jakarta: PT Erlangga.

Sugiyono. (2011). Metode penelitian pendidikan: Pendekatan puantitatif, kualitatif, dan $R \& D$. Bandung: Alfabeta.

Sugiyono. (2011). Statistika untuk penelitian. Bandung: Alfabeta.

Sutopo, Y \& Slamet, A. (2017). Statistika inferensial. Yogyakarta: ANDI.

You, W.J. (2015). Examining the effect of academic procrastination on achievement using LMS data in e-learning. Journal of Educational Technology and Society, 18 (3), 64-74. Diakses dari https://pdfs.semanticscholar.org/5bbd/43044a38b03c22 16d6d84d9b7382b058a284.pdf. Diakses pada tanggal 7 Maret 2017

Yudiaatmaja, F. (2013). Analisis regresi dengan menggunakan aplikasi komputer statistik SPSS. Jakarta: PT Gramedia Pustaka Utama. 


\section{LAMPIRAN}

Tabel 1

Deskripsi Data Penelitian

\begin{tabular}{|c|c|c|c|c|c|c|c|c|c|}
\hline $\begin{array}{c}\text { Variabel } \\
\text { Penelitian }\end{array}$ & $\begin{array}{c}\text { Mean } \\
\text { Teoretis }\end{array}$ & $\begin{array}{c}\text { Mean } \\
\text { Empiris }\end{array}$ & $\begin{array}{l}\text { Standar } \\
\text { Deviasi } \\
\text { Teoretis }\end{array}$ & $\begin{array}{l}\text { Standar } \\
\text { Deviasi } \\
\text { Empiris }\end{array}$ & $X \min$ & $\mathrm{Xmax}$ & $\begin{array}{l}\text { Sebaran } \\
\text { Teoretis }\end{array}$ & $\begin{array}{l}\text { Sebaran } \\
\text { Empiris }\end{array}$ & $\begin{array}{c}\mathrm{t} \\
\text { (sig.) }\end{array}$ \\
\hline Kontrol Diri & 75 & 86,63 & 15 & 5,603 & 72 & 99 & $30-120$ & $72-99$ & $\begin{array}{l}20,328 \\
(0,000) \\
\end{array}$ \\
\hline $\begin{array}{l}\text { Pola Asuh } \\
\text { Autoritatif }\end{array}$ & 122,5 & 145,38 & 24,5 & 5,497 & 132 & 162 & $49-196$ & $132-162$ & $\begin{array}{l}40,774 \\
(0,000)\end{array}$ \\
\hline $\begin{array}{c}\text { Prokrastinasi } \\
\text { Akademik }\end{array}$ & 105 & 99,24 & 21 & 12.093 & 63 & 132 & $42-168$ & $63-132$ & $\begin{array}{l}-4,667 \\
(0,000)\end{array}$ \\
\hline
\end{tabular}

Tabel 2

Uji Normalitas Data Penelitian

\begin{tabular}{cccc}
\hline Variabel & Kolmogorov-Smirnov & Sig. & Kesimpulan \\
\hline Kontrol Diri & 0,934 & 0,347 & Data Normal \\
Pola Asuh Autoritatif & 1,056 & 0,215 & Data Normal \\
Prokrastinasi Akademik & 0,613 & 0,846 & Data Normal \\
\hline
\end{tabular}

Tabel 3

Uji Linearitas Data Penelitian

\begin{tabular}{cccc}
\hline Variabel & Linearity & $\begin{array}{c}\text { Deviation from } \\
\text { Linearity }\end{array}$ & Kesimpulan \\
\hline $\begin{array}{c}\text { Kontrol Diri* Prokrastinasi } \\
\text { Akademik }\end{array}$ & 0,000 & 0,710 & Data Linear \\
$\begin{array}{c}\text { Pola Asuh Autoritatif* } \\
\text { Prokrastinasi Akademik }\end{array}$ & 0,000 & 0,564 & Data Linear \\
\hline
\end{tabular}

Tabel 4

Uji Multikolinearitas Data Penelitian

\begin{tabular}{cccc}
\hline Variabel & Tolerance & VIF & Kesimpulan \\
\hline Kontrol Diri & 0,688 & 1,454 & $\begin{array}{c}\text { Tidak terjadi } \\
\text { multikolinearitas }\end{array}$ \\
Pola Asuh Autoritatif & 0,688 & 1,454 & $\begin{array}{c}\text { Tidak terjadi } \\
\text { multikolinearitas }\end{array}$ \\
\hline
\end{tabular}


Tabel 5

Uji Heteroskedastisitas Data Penelitian

\begin{tabular}{|c|c|c|c|c|c|c|}
\hline \multirow[t]{2}{*}{ Variabel } & \multicolumn{2}{|c|}{$\begin{array}{c}\text { Unstandardized } \\
\text { Coefficients }\end{array}$} & \multirow{2}{*}{$\begin{array}{c}\text { Standardized } \\
\text { Coefficients } \\
\text { (Beta) }\end{array}$} & \multirow[t]{2}{*}{$T$} & \multirow[t]{2}{*}{ Sig. } & \multirow[t]{2}{*}{ Kesimpulan } \\
\hline & B & Std. Error & & & & \\
\hline Kontrol Diri & $-0,105$ & 0,127 & $-0,102$ & $-0,824$ & 0,412 & $\begin{array}{c}\text { Tidak terjadi } \\
\text { heterokedastisitas }\end{array}$ \\
\hline $\begin{array}{l}\text { Pola Asuh } \\
\text { Autoritatif }\end{array}$ & 0,192 & 0,130 & 0,183 & 1,478 & 0,143 & $\begin{array}{c}\text { Tidak terjadi } \\
\text { heterokedastisitas }\end{array}$ \\
\hline
\end{tabular}

Tabel 6

Hasil Uji Regresi Berganda

\begin{tabular}{cccc}
\hline $\mathbf{R}$ & $\boldsymbol{R}$ Square & Adjusted R Square & $\begin{array}{c}\text { Std. Error of the } \\
\text { Estimate }\end{array}$ \\
\hline 0,760 & 0,577 & 0,568 & 7,951 \\
\hline
\end{tabular}

Tabel 7

Hasil Uji Regresi Berganda Signifikansi Nilai F

\begin{tabular}{cccccc}
\hline & Sum of Squares & Df & Mean Square & F & Sig. \\
\hline Regression & 8014,548 & 2 & 4007,274 & 63,392 & 0,000 \\
Residual & 5878,942 & 93 & 63,214 & & \\
Total & 13893,490 & 95 & & & \\
\hline
\end{tabular}

Tabel 8

Hasil Uji Regresi Berganda Nilai Koefisien Beta dan Nilai t Variabel Kontrol Diri dan Pola Asuh Autoritatif terhadap Prokrastinasi Akademik

\begin{tabular}{|c|c|c|c|c|c|}
\hline \multirow[t]{2}{*}{ Variabel } & \multicolumn{2}{|c|}{ Unstandardized Coefficients } & \multirow{2}{*}{$\begin{array}{c}\text { Standardized } \\
\text { Coefficients } \\
\text { (Beta) }\end{array}$} & \multirow[t]{2}{*}{$t$} & \multirow[t]{2}{*}{ Sig. } \\
\hline & B & Std. Error & & & \\
\hline (Constant) & 294,219 & 21,599 & & 13,622 & 0,000 \\
\hline Kontrol Diri & $-1,229$ & 0,176 & $-0,569$ & $-7,001$ & 0,000 \\
\hline $\begin{array}{l}\text { Pola Asuh } \\
\text { Autoritatif }\end{array}$ & $-0,609$ & 0,179 & $-0,277$ & $-3,404$ & 0,001 \\
\hline
\end{tabular}


Tabel 9

Rangkuman Hasil Uji Hipotesis Penelitian

\begin{tabular}{|c|c|c|}
\hline No & Hipotesis & Hasil \\
\hline 1. & $\begin{array}{l}\text { Hipotesis Mayor: } \\
\text { Kontrol diri dan pola asuh autoritatif berperan terhadap } \\
\text { prokrastinasi akademik mahasiswa Program Studi Pendidikan } \\
\text { Dokter Fakultas Kedokteran Universitas Udayana. }\end{array}$ & Diterima \\
\hline 2. & $\begin{array}{l}\text { a. Hipotesis Minor 1: } \\
\text { Kontrol diri berperan terhadap prokrastinasi akademik } \\
\text { mahasiswa Program Studi Pendidikan Dokter Fakultas } \\
\text { Kedokteran Universitas Udayana }\end{array}$ & Diterima \\
\hline & $\begin{array}{l}\text { b. Hipotesis Minor } 2 \text { : } \\
\text { Pola asuh autoritatif berperan terhadap prokrastinasi akademik } \\
\text { mahasiswa Program Studi Pendidikan Dokter Fakultas } \\
\text { Kedokteran Universitas Udayana }\end{array}$ & Diterima \\
\hline
\end{tabular}

